\title{
Editorial convidado
}

\author{
Antonio Richieri-Costa \\ Universidade de São Paulo - Bauru
}

II Congresso Brasileiro de Fonoaudiologia e Genética dos Distúrbios da Comunicação, 2008, Fortaleza - CE

For several instances we have compared the study of communication disorders with the Indian parable of the "Seven blind men and an elephant", very useful as an alert in health services since it works as an example of how reality can be seen (taken) under different perspectives e that in many situations what could be taken as an absolute truth actually represents a relative one due to the differences existing in the interpretation of the facts. We have seemed so many conceptual divergences in the approach of the communication disorders, a widely known heterogeneous condition; no matter the angle we approach it. In communication disorders not always etiological mechanisms are clear, nor the limits existing between superimposed different clinical conditions. It is not unusual to be necessary a variable time of follow up to confirm a definitive diagnosis, so, not always the first diagnostic "label" is the definitive. Communication disorders can be seem within a "quasi continuum" spectrum, ranging from conditions very close to normality to severe communication disorders, that in some instances can be wrongly defined with the same eponym, and we kept as the blind men without to know if we are handling an elephant and its different parts or handling any other animal. This is the greatest challenge for those researchers involved in the study of communication disorders, both in clinical grounds as well as in laboratorial research. It is urgent to determine common denominators that could be understood no matter where and no matter whom are the researchers, from elementary school classes to large research centers within Universities. The solution seems to be reachable through the elaboration of
Em diversas ocasiões comparei o estudo dos distúrbios genéticos da comunicação humana com a fábula dos homens cegos e o elefante, muito usada como alerta em ciências da saúde por ser um grande exemplo, de como a realidade pode ser vista sobre diferentes perspectivas e, que quase tudo que a primeira vista parece ser uma verdade absoluta, de fato se trata apenas de uma verdade relativa, devido às diferentes interpretações. Digo isso porque temos observado divergências conceituais importantes quando lidamos com os aspectos genéticos da comunicação humana, uma condição sabidamente heterogênea seja qual seja o ângulo de abordagem. Nos distúrbios da comunicação humana nem sempre os mecanismos etiológicos são claros e nem os limites entre situações clínicas que se sobrepõem Não é incomum a necessidade de um período de seguimento para que o diagnóstico definitivo possa ser confirmado, assim, nem sempre a primeira impressão diagnóstica é válida. Os distúrbios da comunicação podem ser vistos dentro de um espectro "quasi continuum" que se estende desde limites muito próximos da normalidade até graves distúrbios do comportamento e da linguagem, que e em situações incomuns recebem o mesmo rótulo diagnóstico, portanto abrem-se as possibilidades de que possamos estar tateando diferentes partes de um mesmo elefante ou mais importante ainda que estejamos tateando diferentes animais. Este é o grande desafio que se apresenta, hoje, aos estudiosos dos distúrbios da comunicação humana, sejam eles da área clínica ou laboratorial. Faz-se urgente a necessidade de um linguajar comum que seja compreendido onde quer que seja e por quem quer que seja, sem importar onde estejam, em salas 
multidisciplinary task-force groups representing different schools of thought existing inside the Universities to broadly discuss the overall concepts in communication disorders. It is mandatory to left behind prejudices, intolerances and conceptual inflexibilities, and to have open ideas to receive the new concepts and scientific advances. Main goals of the multidisciplinary team-works should be the search for the direction to the organization of efficient and agile system for dialogue and diagnosis between different researchers, to develop consensual clinical definitions, rules, and directives toward the ideal management of the communication disorders, to generate realist research topics in direction to the elucidation of the etiopathogenetic basis of the communication disorders resulting in useful responses to the patients and health services in general.

Recently, during the "II Congresso Brasileiro de Fonoaudiologia e Genética dos Distúrbios da Comunicação" Fortaleza - CE., Brazil, a team of multidisciplinary researchers presented an exciting meeting where they reinforced the necessity to develop multidisciplinary task-forces, and the necessity to establish collaborative programs between different national and international centers. More and more the interfaces between genetics and speech pathology have been showed a fruitful way in developing researches, however, the resistance of some editorial boards to analyze papers from this area still remains unchangeable. Urge that other professionals from different areas of communication disorders start to organize this type of meeting calling attention of governmental agencies and departments in sense to provide support and funding to the study of these challenging human disorder. It should be viewed as a paramount point mainly in the young population facing scholar problems where environment and genetics play a significant role and differential diagnosis is crucial. de aula ou nos grandes centros de estudos da linguagem. Tal meta só pode ser alcançada através da constituição de grupos-tarefa multidisciplinares que representem as diferentes escolas de pensamento albergadas dentro das universidades. Como o próprio termo designa a idéia de UNIVERSO, é imperativo que o ranço de velhos conceitos seja deixado de lado, e que as idéias estejam abertas aos novos conceitos e avanços da ciência. A constituição destas equipes multidisciplinares deve ter como objetivos principais a capacidade de organizar um sistema ágil e eficaz de diálogo diagnóstico (que vá além do CID), desenvolver definições clínicas consensuais, normas e diretivas para o manejo adequado dos $\mathrm{DCH}$, gerar tópicos de pesquisa realísticos direcionados ao esclarecimento das bases etiopatogênicas dos DCH e que possam facilitar a geração de respostas apropriadas e adequadas aos serviços comunitários de saúde.

Esta foi a abordagem mostrada durante o "II Congresso Brasileiro de Fonoaudiologia e Genética dos Distúrbios da Comunicação" realizado em Fortaleza - CE., quando profissionais de diferentes áreas abrilhantaram um encontro multidisciplinar dos mais relevantes na área de DCH enfatizando a necessidade do estabelecimento de programas de intercâmbio entre diferentes centros - nacionais e internacionais. As interfaces entre os distúrbios da comunicação e a genética clínica e molecular estão abertas e apontam um caminho fértil para o desenvolvimento de pesquisas conjuntas, no entanto, a resistência de alguns editores para a análise deste tipo de trabalho ainda permanece imutável, principalmente no impenetrável círculo dos PERIÓDICOS internacionais. Urge que os profissionais das mais diversas áreas abrigadas sob o epônimo de DCH realizem novos encontros com esta visão multidisciplinar tão bem mostrada pelos organizadores Cearenses no sentido de sensibilizar as agências governamentais de fomento, possibilitando que todos envolvidos nesta árdua tarefa tenham sua hora e vez. Devem ser enfatizadas as populações de escolares que enfrentam problemas de aprendizagem, onde aspectos ambientais se mesclam com aqueles de etiologia genética, determinando problemas quanto ao diagnóstico diferencial às vezes insolúveis, e assim quem sabe consigamos ver além das pequenas partes, o elefante como ele é ao todo.

Agradecimentos especiais: Renata Haguete (Fonoaudióloga do Hospital Infantil Albert Sabin e Professora da Unifor); Doutora Erlane Ribeiro (Geneticista do Hospital Infantil Albert Sabin - HIAS/CE); Associação Cearense de Doenças Genéticas (ACDG); e a todos organizadores. 